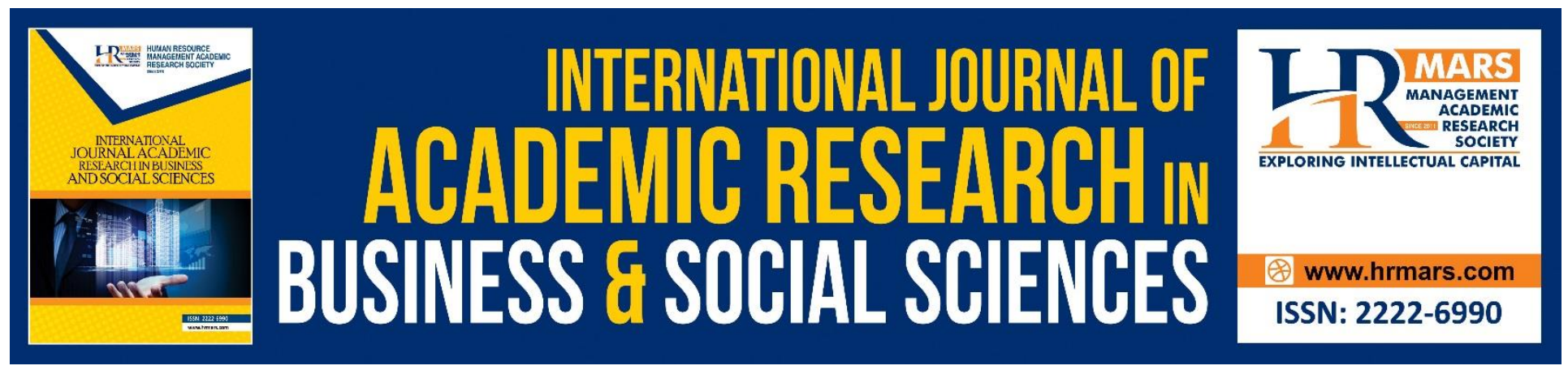

\title{
Government Ownership and Competitive Advantage: The Impact on Performance of Indonesian Regional Development Banks
}

\section{Donal Devi Amdanata \& Noorhayati Mansor}

To Link this Article: http://dx.doi.org/10.6007/IJARBSS/v8-i12/5070

DOI: $10.6007 /$ IJARBSS/v8-i12/5070

Received: 17 Oct 2018, Revised: 21 Dec 2018, Accepted: 28 Dec 2018

Published Online: 29 Dec 2018

In-Text Citation: (Amdanata \& Mansor, 2018)

To Cite this Article: Amdanata, D. D., \& Mansor, N. (2018). Government Ownership and Competitive Advantage: The Impact on Performance of Indonesian Regional Development Banks. International Journal of Academic Research in Business and Social Sciences, 8(12), 755-765.

\section{Copyright: (C) 2018 The Author(s)}

Published by Human Resource Management Academic Research Society (www.hrmars.com)

This article is published under the Creative Commons Attribution (CC BY 4.0) license. Anyone may reproduce, distribute, translate and create derivative works of this article (for both commercial and non-commercial purposes), subject to full attribution to the original publication and authors. The full terms of this license may be seen at: http://creativecommons.org/licences/by/4.0/legalcode

Vol. 8, No. 12, 2018, Pg. 755 - 765

Full Terms \& Conditions of access and use can be found at http://hrmars.com/index.php/pages/detail/publication-ethics 


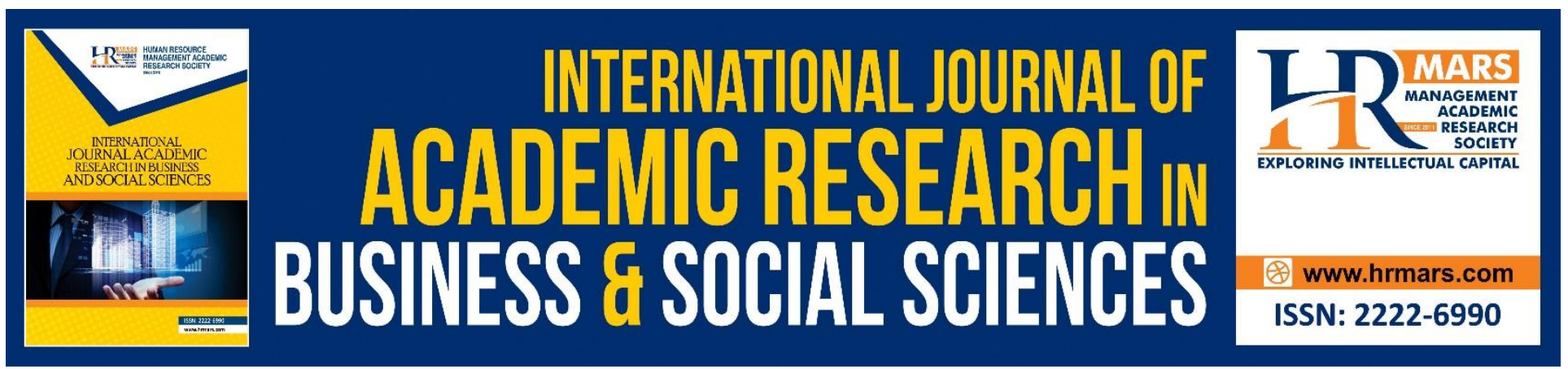

\title{
Government Ownership and Competitive Advantage: The Impact on Performance of Indonesian Regional Development Banks
}

\author{
Donal Devi Amdanata \\ Sekolah Tinggi Ilmu Ekonomi Riau, Pekanbaru, Indonesia \\ Email: donaldev.mec@gmail.com \\ Noorhayati Mansor \\ Faculty of Economics and Management Sciences, Universiti Sultan Zainal Abidin,Terengganu, \\ Malaysia. \\ Email: nhayatimansor@unisza.edu.my
}

\begin{abstract}
Local governments in Indonesia are allowed to establish their own Regional Development Banks (RDB) in their respective provinces. Apart from Indonesian national banks, these RDBs also have to compete with privately-owned and international banks in the country. In addition, each RDB from various regions also have to compete with one another. This study aims to determine the impact of local government ownership and competitive advantage on the financial performance of the RDBs. The influence of competitive advantage of state-owned banks has not yet been studied. Data for RDBs for the year 2015 were gathered from their annual reports available from the websites. Additional secondary data were also obtained from the Indonesian Central Bank and Financial Services Authority (FSA). The final analyses using OLS regression involved a total of 26 RDBs throughout Indonesia. The results of this study show that only capital adequacy as a proxy of government ownership has a positive and significant impact (at 1 percent level) on the performance of RDBs while competitive advantage does not contribute to their financial success. The results contribute to improve the current understanding of RDBs' performance as government banks. This study also provides input to local governments in managing their funds and resources to ensure the sustainability of RDBs.
\end{abstract}

Keywords: Regional Development Bank, Government Linked Companies, Government Ownership, Competitive Advantage. 
INTERNATIONAL JOURNAL OF ACADEMIC RESEARCH IN BUSINESS AND SOCIAL SCIENCES Vol. 8, No. 12, Dec, 2018, E-ISSN: 2222-6990 @ 2018 HRMARS

\section{Introduction}

Research on government ownership is not new. For a long time, many scholars have studied government ownership in corporations (Borisova, Brockman, Salas, \& Zagorchev, 2012; Lau \& Tong, 2008; Ting \& Lean, 2015; Wicaksono, 2008). There are also research which specifically focus on government ownership in banking (e.g., Dinç, 2005; La Porta, Lopez-De-Silanes, \& Shleifer, 2002; Pina, Torres, \& Bachiller, 2016; Sapienza, 2004; Shen, Hasan, \& Lin, 2014; Shen \& Lin, 2012). In addition, there are also research work specializing on local government ownership of regional banking (Agustin, 2016; Buchory, 2014, 2016; Jia \& Zhang, 2010).

In Indonesia, Regional Development Banks (RDBs) were established by provincial governments to support developmental effort at the regional level (Indonesian Government, 1962). To fulfill these objectives, RDBs were given numerous assistance and preferential treatments from the government since they are government-owned banks, (Luo, Xue, \& Han, 2010). According to Okhmatovskiy (2010), it is reasonable for the RDBs to receive special privileges and government's support since RDBs are registered as local companies, and thus, their assets belong to the respective states. At the same time, the RDBs are also associated with disadvantageous and poor image automatically attached to them simply because they are government-owned. In other words, in comparison to regular banks RDBs are also burdened with disadvantages in addition to the favorable government assistance provided to them.

According to Huang, Xie, Li, \& Reddy (2016) there are three weaknesses associated with governmentowned or Government-Linked Companies (GLCs). Firstly, they have only a small chance to compete outside of their regions. Secondly, market orientation sets by the government tend to hamper development efforts outside their business areas. Thirdly, for the RDBs in particular, competitions with other national and private banks, and international banks may reduce their desired profits. Although Huang et al. (2016) reveal the shortfalls of government ownership in these companies they also suggest that there are opportunities that can be utilized by the GLCs.

Since the assets of these GLCs are owned by the government, the RDBs earn a special status not awarded to other competing banks which may provide an advantage in terms of improving their performance. This special privilege for RDBs may reduce the pressure for them in competing with other non-government banks to optimize their profits. However, taking advantage of the special status does not necessarily imply exploiting the privilege. Rather, the status carries with it the duty and responsibility for RDBs to practice good corporate governance (CG).

One of the objectives of establishing the RDBs is to help finance the development of provincial and district governments in Indonesia. These regional or provincial governments have limitations in collecting funding and financing. The regional governments can only raise community taxes but cannot perform activities as business enterprises, and they are not allowed to form agreements with business enterprises. Therefore, RDBs as intermediary institutions are needed to support the provincial governments in conducting fund-raising activities and fund disbursements. This study aims to determine the impact of local government ownership and competitive advantage on the financial 
INTERNATIONAL JOURNAL OF ACADEMIC RESEARCH IN BUSINESS AND SOCIAL SCIENCES

Vol. 8, No. 12, Dec, 2018, E-ISSN: 2222-6990 @ 2018 HRMARS

performance of the RDBs. To date, the impact of competitive advantage of Indonesian state-owned banks has not yet been studied.

\section{Literature Review}

\section{Government Ownership}

RDBs represent local government-owned banks, and they are authorized among others, to collect public funds. Almost all local governments in Indonesia deposit state funds allocated to them in the respective RDBs which they established. Having the 'automatic' large deposits of state funds in these regional banks help them in reducing the efforts to raise bank deposits for the RDBs.

In Singapore, it has been widely reported that its GLCs manage to produce excellent performances even though they operate with low government support and at the same time have to compete with private companies mainly because they are managed by professionals and not operated as government entities.

Pina, Torres, \& Bachiller (2016) conducted a study of 45 savings banks in Spain and found that banks which have connections with politicians show poor overall performance. This low or lack of performance is due to the strong power of politicians to influence the policies of companies which are linked to or under the supervision of the government. In line with this research, Sapienza (2004) provides further support for the finding that politicians have a strong influence on government companies.

\section{Competitive Advantage}

The concept of competitive advantage has grown rapidly for a long time. At first competitive advantage emphasized price and distribution control (Johnson \& Busbin, 2000), now it has developed in a broader direction such as green technology (Song \& Wang, 2017). As the concept of competitive advantage develops in the science of strategic management (Johnson \& Busbin, 2000), the definition from experts towards competitive advantage is also increasingly diverse (Wiggins \& Ruefli, 2002). One researcher who defines competitive advantage with the initial concept is Bridoux (2004) which states that competitive advantage as a superior differentiation and lower costs by comparison with the marginal (breakeven) competition in the product market.

The company performance is the result of creating value for customers or reducing costs. However, on a macro competitive scale can also include proximity to the government in order to penetrate an increasingly competitive market (Johnson \& Busbin, 2000). One example is the research of Bachiller \& Garcia-lacalle (2018) which reveals that the proximity of the Spanish government's savings bank to the government can increase the profitability of the company. In short, competitive advantage may be attained when entities occupy their positions. Having the unique conditions help the companies to arrive at better performance at reduce efforts. Among others competitive advantages can be derived from increased production efficiency or increased capital utilization. 
As a state-owned bank, RDBs have the advantage of getting direct awards for the business activities of the government without having to compete with other banks. Through special provisions of the law or regulations the local governments have no other options but to utilize the banking services of the RDBs. The financial services provided by RDBs for the local governments include long-term and short-term fund deposits and staff payroll. Even though RDBs are given the special status to provide the banking services and facilities for the state governments they still have to follow the regulations of Bank Indonesia as the central bank as well as the regulations of the Financial Services Authority (FSA) imposed on other banks. These requirements are necessary so that the RDBs remain as intermediary institutions to conduct public fundraising. FSA has also published CG guidelines for banks in Indonesia, and RDBs are obligated to implement this CG guideline.

\section{Financial Performance}

Every business strives for long-term sustainability and profits remain as one of the key indicators commonly used to measure performance. Profit, however, is just a short-term measure and may not guarantee future success. To survive in the industry, companies must also ensure a continuing increase in assets and capital growth. For the RDBs, it is crucial to gain the public's confidence through superior performance to justify the governments' support for them. By demonstrating the desired performance, these GLCs also provide motivations for the local community to participate in their business and become the customers of RDBs.

Ang \& Ding (2006) compare the performance of government-owned companies and private companies in Singapore. The results show that the government-owned company has more value than the private companies. Similar findings were reported by Ab Razak, Ahmad, \& Aliahmed Jober (2011) that the performance of the government-owned company is better in comparison with private companies. Among others, a study of GLCs in Indonesia as reported by Amdanata \& Mansor (2016) provides evidence that GLCs which implement good CG consistently performed better than those GLCs which neglected the practice.

Currently, in terms of financial rating RDBs' performance are still below those of the state-owned or privately-owned national banks (Buchory, 2016). Also, in comparison to national banks, the source of capital for RDBs depends primarily on the funds deposited by the local governments. For example, for the year 2015 the capital of DKI Bank which is currently the best RDB in Indonesia, is only Rp11.5 trillion. This amount represents a small fraction (12.33\%) of the capital of Bank Mandiri for that year. This ratio suggests that the financial capital of RDBs is very small in comparison to the privatelyowned bank.

\section{Research Methodology}

Data for RDBs were collect from their published Annual Reports for the year 2015 which were available from their official websites. In total, data from 26 RDBs from all of the 26 provinces across Indonesia were analyzed. Overall, the RDBs are relatively large and 100 per cent of the equity are owned and controlled by the state government. 
The dependent variable for this study is RDBs' performance as measured by ROA. It is a ratio of profit before tax and interest on RDBs outstanding loan. Many studies use indicators such as Return on Assets (ROA) and Return on Equity (ROE) to proxy enterprises' performance. For example, Core, Holthausen, \& Larcker (1999) use ROA to examine the impact of corporate governance on firm performance. Hamid (2009) in his study of the relationship between the structure of corporate governance and company's performance use both ROA and ROE to measure performance. Similarly, Jiang, Laurenceson, \& Tang (2008) also use ROE and ROA in measuring firm performance in their study in China.

Based on previous research two variables are used to measure state ownership. Firstly, the amount of paid-up capital provided by the local government was used by Chou, Hamill, \& Yeh (2016). Secondly, the capital adequacy ratio was used by Buchory (2016). This study uses capital adequacy ratio (CAR) following Buchory (2016). Competitive advantage of the government is represented by two variables. These are government fund placements (GOVMONEY) and payroll services (PAYROLL). A control variable, SIZE is used and measured by the availability of RDB branches in other provinces.

The following model was used is in this study:

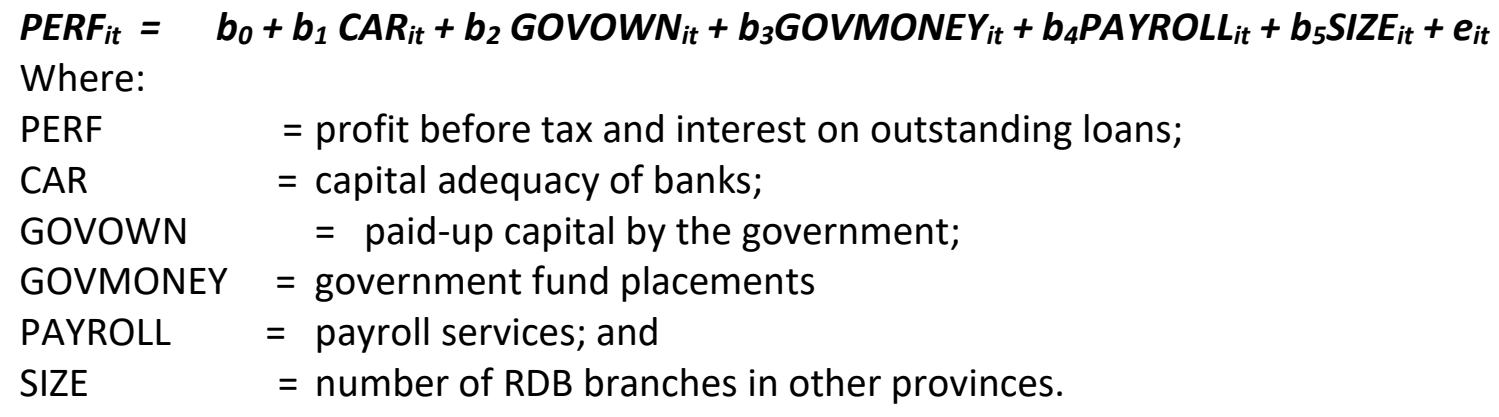

\section{Findings and Discussion}

The Ordinary Least Squares (OLS) regression was used to examine the relationships between the variables. Table 1 provides the summary statistics for the model. The explanatory power of the model is 76.1 per cent indicating that 76.1 per cent of the variability in RDBs performance is explained by the independent variables. 
INTERNATIONAL JOURNAL OF ACADEMIC RESEARCH IN BUSINESS AND SOCIAL SCIENCES Vol. 8, No. 12, Dec, 2018, E-ISSN: 2222-6990 @ 2018 HRMARS

Table 1 Regression Results

\begin{tabular}{lrrrr}
\hline \hline \multicolumn{1}{c}{ Variable } & Coefficient & Std. Error & t-Statistic & Prob. \\
\hline \hline C & -0.966508 & 0.706511 & -1.368001 & 0.1865 \\
CAR & 0.125484 & 0.020422 & 6.144459 & 0.0000 \\
GOVERNMENT_OWNERSHIP & 0.031918 & 0.011509 & 2.773355 & 0.0117 \\
GOVERNMENT_MONEY & -0.001111 & 0.000243 & -4.569662 & 0.0002 \\
PAYROLL & 0.073429 & 0.265451 & 0.276620 & 0.7849 \\
SIZE & 0.240599 & 0.239995 & 1.002517 & 0.3281 \\
\hline \hline R-squared & 0.761705 & Mean dependent var & 2.768846 \\
Adjusted R-squared & 0.702132 & S.D. dependent var & 0.925312 \\
S.E. of regression & 0.505010 & Akaike info criterion & 1.670699 \\
Sum squared resid & 5.100711 & Schwarz criterion & 1.961029 \\
Log likelihood & -15.71909 & Hannan-Quinn criter. & 1.754304 \\
F-statistic & 12.78595 & & \\
Prob(F-statistic) & 0.000012 & & \\
\hline \hline
\end{tabular}

Dependent Variable: ROA

Method: Least Squares

Sample: 126

Included observations: 26

The results above show a significant effect of competitive advantage on RDB performance. The placement of local government money (GOVMONEY) in RDB has a significant relationship of 0.0002 at $1 \%$ confidence level. This result is consistent with Maury's (2018) study which proves that there is a competitive advantage effect on performance. While the other competitive advantage variable, PAYROLL despite showing a positive relationship of 0.0734, PAYROLL did not have a significant effect on the financial performance of RDB. The impact of competitive advantage on RDBs' success is interesting. GOVMONEY which shows a negative sign while PAYROLL results in a positive coefficient. Thus, the government funds and state funds deposited in RDBs have significant effects on their financial performance.

Local government ownership of RDB has a positive and significant relationship to the financial performance of RDB. First is the CAR which shows a positive relationship of 0.1254 and a significant relationship of 0.0000 at a confidence level below $1 \%$. The amount of shares of local government ownership (GOVOWN) against RDB also shows a positive relationship of 0.0139 and a significant relationship of 0.0011 at the degree of confidence below $5 \%$. While the variable control SIZE showed a positive relationship of 0.2405 , but SIZE did not show a significant relationship to the financial performance of RDB. 
CAR in this study measures capital strength provided by the stakeholders (i.e., local government). This result provides evidence that the state ownership of RDBs is very crucial to ensure the financial performance and thus, the continuing success of RDBs. This is the relationship between CAR and banks' financial performance as reported by Buchory (2016). Provincial government ownership of RDB (GOVOWN) shows significant effect on the RDBs performance. This finding implies that the provincial government has a strong influence on RDBS and it represents the largest shareholders of RDBs. Nevertheless, RDBs are not only owned by the provincial government but also the district government with different practices and political influence on RDBs.

In terms of SIZE of RDB as measured by the branches in other provinces, the results suggest that this variable also has no effect on the performance. This is the place where they are established since the competition does not contribute significantly to their performance. In this study also shows Fstatistics (prob) $0.000012<0.05$ and this shows that all independent variables simultaneously affect the financial performance of RDB.

\section{Conclusion}

RDB as a regional bank has insufficient capital compared to state or private banks. A key factor contributing to the financial success of RDB is the capital adequacy ratio and capital placement from the government (CAR and GOVOWN). In accordance with estimates, competitive advantage in terms of government savings handled by RDB shows significant results on the company's financial performance. However, the significance of these results shows the positive and negative sides. Positively of course with the support of the local government, RDB can continue to improve the performance of the company. While the RDB is still owned by the local government, RDB continues to have such a competitive advantage.

But precisely, the positive side also has a negative side. In line with what was conveyed by Huang et al. (2016), the negative side is that RDB will continue to depend on the regional government. In this case, of course, it will reduce the company's independence of the company in the future and to develop the company. Dependence on the owner of this capital will someday make RDB challenging to make the company bigger.

RDB's difficulties in making a company become can be proven by the insignificance of the relationship between the size of the bank and the company's performance. By setting up branches in other provinces, it does not have any effect on financial performance, even though with increasing branches or increasing size, the bank's market share becomes more extensive, but in this study, it results in the opposite result.

Focusing on the banking business only in areas where RDB was formed could help RDB to improve performance because establishing branches in other provinces did not contribute significantly to their financial success. As a local bank for the government, RDB must try to compete with other national and international banks and take advantage of the competitive advantages received from the government. RDB must focus and be creative in making programs to establish relations with local 
INTERNATIONAL JOURNAL OF ACADEMIC RESEARCH IN BUSINESS AND SOCIAL SCIENCES Vol. 8, No. 12, Dec, 2018, E-ISSN: 2222-6990 C 2018 HRMARS

governments because that is where the benefits of RDB compare to other banks. Of course, these programs are made for a broader market so that banks can slowly reduce dependence on local governments.

Systematic planning for disbursement of funds at the end of the year can also help RDB to reduce the variability of funds and create a more stable fund management system. Continuously improving its performance will assist in long-term sustainability and provide services that are appropriate for their community. Future research should conduct longitudinal studies to examine the effect of government support and competitive advantage on the overall success of the RDB by incorporating an integrated approach to performance.

\section{*Corresponding Author:}

Noorhayati Mansor

Faculty of Economics and Management Sciences,

Universiti Sultan Zainal Abidin,

21300 Kuala Terengganu,

Terengganu, Malaysia.

Email:nhayatimansor@unisza.edu.my

\section{References}

Ab Razak, N. H., Ahmad, R., \& Aliahmed Jober, H. (2011). Does Government Linked Companies (GLCs) Perform Better Than Non-GLCs? Evidence from Malaysian Listed Companies. Journal of Applied Finance and Banking, 1, 213-240.

Agustin, H. (2016). Financial performance Islamic banking unit in Indonesia: A comparative study private banks and regional development banks. International Journal of Economic Research, 13(4), 1399-1409.

Amdanata, D. D., \& Mansor, N. (2016). Perbandingan Penerapan Good Corporate Governance pada BUMD Provinsi Riau dengan BUMD DKI Jakarta (Perbandingan dengan PT. Pembangunan Jaya Ancol). In 1st CELSCiTech 2016 (Vol. 1, pp. 1-5). Pekanbaru.

Ang, J. S., \& Ding, D. K. (2006). Government ownership and the performance of government-linked companies: The case of Singapore. Journal of Multinational Financial Management, 16(1), 6488. https://doi.org/10.1016/j.mulfin.2005.04.010

Bachiller, P., \& Garcia-lacalle, J. (2018). Corporate governance in Spanish savings banks and its relationship with financial and social performance. Management Decision. https://doi.org/10.1108/MD-01-2017-0079

Borisova, G., Brockman, P., Salas, J. M., \& Zagorchev, A. (2012). Government ownership and corporate governance: Evidence from the EU. Journal of Banking and Finance, 36(11), 29172934. https://doi.org/10.1016/j.jbankfin.2012.01.008

Bridoux, F. (2004). A resource-based approach to performance and competition: an overview of the connections between resources and competition. Luvain, Belgium Institut et de Gestion, Universite Catholique de Louvain, 110, 1-21. https://doi.org/10.1177/014920630102700602

Buchory, H. A. (2014). Analysis of the effect of capital, credit risk and profitability to implementation 
INTERNATIONAL JOURNAL OF ACADEMIC RESEARCH IN BUSINESS AND SOCIAL SCIENCES

Vol. 8, No. 12, Dec, 2018, E-ISSN: 2222-6990 @ 2018 HRMARS

banking intermediation function (study on regiondevelopment bank all over Indonesia year 2012). International Journal of Business, Economics and Law, 4(1), 133-144.

Buchory, H. A. (2016). Determinants of banking profitability in Indonesian regional development bank. Actual Problems of Economics, 177(3), 308-318.

Chou, H.-I., Hamill, P. A., \& Yeh, Y.-H. (2016). Are all regulatory compliant independent director appointments the same? An analysis of Taiwanese board appointments. Journal of Corporate Finance, 1-17. https://doi.org/10.1016/j.jcorpfin.2016.10.012

Core, J. E., Holthausen, R. W., \& Larcker, D. F. (1999). Corporate governance, chief executive officer compensation, and firm performance. Journal of Financial Economics, 51(3), 371-406. https://doi.org/10.1016/S0304-405X(98)00058-0

Dinç, I. S. (2005). Politicians and banks: Political influences on government-owned banks in emerging markets. Journal of Financial Economics, 77(2), 453-479. https://doi.org/10.1016/j.jfineco.2004.06.011

Hamid, A. A. (2009). The Corporate Governance Structures of GLCs and NGLCs and Firm Performance in Malaysia. In 7th International Conference Accounting and Finance in Transition (pp. 551-573).

Huang, Y., Xie, E., Li, Y., \& Reddy, K. S. (2016). Does state ownership facilitate outward FDI of Chinese SOEs? Institutional development, market competition, and the logic of interdependence between governments and SOEs. International Business Review, 26(1), 176188. https://doi.org/10.1016/j.ibusrev.2016.06.005

Jia, N., \& Zhang, H. (2010). Impact of government ownership on investment banks' underwriting performance: Evidence from China. Asia-Pacific Journal of Financial Studies, 39(2), 198-228. https://doi.org/10.1111/j.2041-6156.2010.00010.x

Jiang, B. B., Laurenceson, J., \& Tang, K. K. (2008). Share reform and the performance of China's listed companies. China Economic Review, 19(3), 489-501. https://doi.org/10.1016/j.chieco.2008.02.001

Johnson, J. T., \& Busbin, J. W. (2000). The Evolution of Competitive Advantage: Has Virtual Marketing Replaced Time-Based Competition? Competitiveness Review: An International Business Journal Incorporating Journal of Global Competitiveness, 10(2), 153-159. https://doi.org/10.1108/eb046408

La Porta, R., Lopez-De-Silanes, F., \& Shleifer, A. (2002). Government Ownership of Banks. Journal of Finance, 57(1), 265-301. https://doi.org/10.1111/1540-6261.00422

Lau, Y. W., \& Tong, C. Q. (2008). Are Malaysian Government-Linked Companies ( GLCs ) Creating Value ? International Applied Economics and Management Letters, 1(1), 9-12.

Luo, Y., Xue, Q., \& Han, B. (2010). How emerging market governments promote outward FDI: Experience from China. Journal of World Business, 45(1), 68-79. https://doi.org/10.1016/j.jwb.2009.04.003

Okhmatovskiy, I. (2010). Performance implications of ties to the government and SOEs: A political embeddedness perspective. Journal of Management Studies, 47(6), 1020-1047. https://doi.org/10.1111/j.1467-6486.2009.00881.x

Pina, V., Torres, L., \& Bachiller, P. (2016). Political Influence and the Performance of Nonprofit Spanish Banks. Nonprovit Management \& Leadership, 26(4), 471-488. 
INTERNATIONAL JOURNAL OF ACADEMIC RESEARCH IN BUSINESS AND SOCIAL SCIENCES

Vol. 8, No. 12, Dec, 2018, E-ISSN: 2222-6990 @ 2018 HRMARS

https://doi.org/10.1002/nml

Sapienza, P. (2004). The effects of government ownership on bank lending. Journal of Financial Economics, 72(2), 357-384. https://doi.org/10.1016/j.jfineco.2002.10.002

Shen, C. H., Hasan, I., \& Lin, C. Y. (2014). The Government's Role in Government-owned Banks. Journal of Financial Services Research (Vol. 45). https://doi.org/10.1007/s10693-013-0168-0

Shen, C. H., \& Lin, C. Y. (2012). Why government banks underperform: A political interference view. Journal of Financial Intermediation, 21(2), 181-202. https://doi.org/10.1016/j.jfi.2011.06.003

Song, M., \& Wang, S. (2017). Market competition, green technology progress and comparative advantages in China. Management Decision.

Ting, I. W. K., \& Lean, H. H. (2015). Does Government Ownership Matter? Comparative Study Between GLCS and NGLCS in Malaysia. The Singapore Economic Review, 60(2), 1550019-11550019-22. https://doi.org/10.1142/S0217590815500198

Wicaksono, A. (2008). Indonesian State-Owned Enterprises: The Challenge of Reform. Southeast Asian Affairs, 2008(1), 146-167. https://doi.org/10.1355/SEAA08I

Wiggins, R. R., \& Ruefli, T. W. (2002). Sustained Competitive Advantage: Temporal Dynamics and the Incidence and Persistence of Superior Economic Performance. Organization Science, 13(1), 81-105. https://doi.org/10.1287/orsc.13.1.81.542 